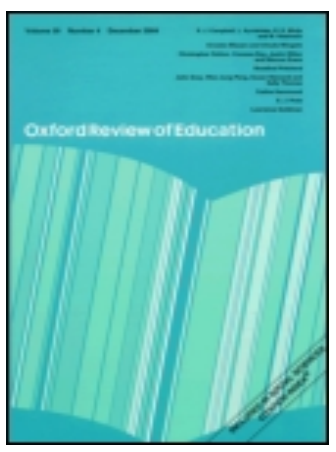

Oxford Review of Education

\title{
Citizenship education in Turkey: inclusive or exclusive
}

\section{Başak Ince}

To cite this article: Bașak Ince (2012) Citizenship education in Turkey: inclusive or exclusive, Oxford Review of Education, 38:2, 115-131, DOI: 10.1080/03054985.2011.651314

To link to this article: http://dx.doi.org/10.1080/03054985.2011.651314

册 Published online: 24 Feb 2012.

Submit your article to this journal $\llbracket$

Џll Article views: 876

Q View related articles $\square$

Citing articles: 9 View citing articles 달 


\title{
Citizenship education in Turkey: inclusive or exclusive
}

\author{
Başak İnce* \\ Bilkent University, Turkey
}

\begin{abstract}
This paper scrutinises citizenship education in Turkey from the foundation of the Turkish Republic (1923) to the present and explores the extent to which it encourages inclusive or exclusive concepts of national identity and citizenship. In Turkey, where there are citizens belonging to ethnic and religious minorities, civic education plays a prominent role for promoting tolerance among citizens. Using framing questions from phase one of the International Association for the Educational Achievement's (IEA) research of Civic Education Across Countries, the civic education textbooks of Turkey are examined to determine the extent to which they promote democracy and human rights, make positive references to ethnic and religious minorities, and promote social cohesion. As Turkey was not included in phase one of the IEA study, the paper provides original information for comparative studies, reconsideration of citizenship education in multicultural societies and promoting an active national citizenry in Turkey.
\end{abstract}

Keywords: citizenship; national identity; minorities; citizenship education; Turkey

\section{Introduction}

According to the World Values Survey Association's 2008 research, Turkey is distrustful of foreigners and minority citizens. Of the survey's respondents, $44 \%$ did not trust foreigners 'very much', while $29 \%$ did not trust them at all. Tolerance toward minority citizens is also very low in Turkey. For instance, among Turkish respondents, $25 \%$ viewed people unfavourably who speak a language other than Turkish. In addition, respondents feel that the most important criterion for citizenship is to obey Turkish laws. These results indicate that there is an urgent need to re-examine the civic education that is taught in schools, which, ideally, plays an important role in promoting tolerance among citizens. If we want

\footnotetext{
*Bilkent University, Department of Political Science, 06800, Bilkent-Ankara-Turkey. Email: basakince@bilkent.edu.tr
}

ISSN 0305-4985 (print)/ISSN 1465-3915 (online)/12/020115-17

(C) 2012 Taylor \& Francis

http://dx.doi.org/10.1080/03054985.2011.651314 
citizens of diverse societies to develop the 'right' attitudes and dispositions, we should encourage civic education that teaches respect for differences while providing the necessary skills for democratic discussion about these differences (Brighouse, 2000, 2006; Gutmann, 2000).

Turkey is home to many predominantly Muslim ethnic and linguistic communities, such as Kurds, Lazes, Romas, Circassians and Arabs. There are also Alevis, who belong to a denomination of Islam and constitute the largest religious minority in Turkey. Non-Muslim minorities such as Jews, Armenians and Greeks also live in Turkey. Citizenship education has been a vital part of the Republic's project to create a modern homogeneous nation-state out of the multi-ethnic Ottoman Empire.

While civic education programmes have been newly introduced into the curricula of several European countries, they have been taught in Turkey since the early years of the Republic. Of the studies exploring civic education in Turkey (Üstel, 1996; Kıncal, 2002; Gök, 2003; Üstel, 2005, Çayır \& Gürkaynak, 2008), however, none uses phase one of the International Association for Educational Achievement's (IEA) data and compares the Turkish case with other diverse societies. In its Civic Education Across Countries research, the IEA covered 24 countries and was concerned in its first-stage report with exploring and clarifying how civics was conceptualised and understood in each country (Torney-Purta et al., 1999). As Turkey was not included in the IEA survey, this paper provides new information for comparative studies, reconsidering citizenship education in multicultural societies, and promoting an active national citizenry in Turkey.

\section{Methodology}

The following research methods are used in this study:

- a review of Turkish literature on civic education;

- a content analysis of the civic education curriculum and associated textbooks in Turkish schools between 1923 and 2010;

- a content analysis of books and learning materials developed by non-governmental organisations working in the field of civic education;

- a comparative analysis of documentation concerning civic education from four other multicultural countries: France, England, Greece and Cyprus.

The data for this article come from curricula for Turkish primary and junior high schools $^{1}$ (applicable to children from seven to 14 years old). Turkey has a population of 73 million, about 21 million of whom are under 15 years old. Of this sector, more than ten million are enrolled in educational institutions. ${ }^{2}$ Education in Turkey is predominantly under state responsibility. The Ministry of National Education prepares the curricula for all subjects, and its approval is required for private publishing companies to introduce new textbooks. I selected the texts to be studied from Turkey's national library in Ankara, which holds a copy of almost all Turkey's published textbooks. My analysis of the textbooks was not 
comprehensive, however, due to limited data on their usage. For this reason I chose to study the texts that were and are most widely used.

The data set for this study is constructed by sampling Turkey's civics textbooks for four time periods: 1923-1946, 1946-1960, 1960-1980 and 1980-2010. This periodisation reflects the most important developments in Turkish political history and is useful for structuring an understanding of the emergence of the notion of citizenship and the shifts it has made since the establishment of the Republic. Civic education is a subject vulnerable to political and social conditions; changes of perspectives and ideals in the dominant political discourse affect its title, content and the pedagogical discourse used to justify its importance.

I examined the textbooks for primary and junior high schools using three of the 18 framing questions in phase one of the above-mentioned IEA study. I selected Core International Framing Questions 1, 2 and 3, titled, respectively, Democracy, Institutions, Rights, and Responsibilities (Figure 1), National Identity and Relations between Nations (Figure 2) and Social Cohesion and Social Diversity (Figure 3).

I apply these questions to the civics textbooks in Turkey from 1923 to the present, giving special attention to the extent to which the perspectives of minority groups, such as non-Muslims, Kurds and Alevis, are included and the extent to which the texts promote democracy and human rights and teach young students how to live together. Gender inequality in civics texts published during the Republican period is a huge issue; women are not highlighted as political models, gender-related topics are rarely addressed, and political action by females is rarely portrayed. This topic, however, is beyond the scope of this article, and thus I only discuss the ethnic and religious aspects of citizenship.

As it is unmanageable to compare Turkey with all 24 countries that participated in phase one of the IEA study, I selected France, ${ }^{3}$ England, Greece and Cyprus

- Given that democracy is a central concept, what does it mean in the national context and what are young people expected or likely to learn about it?

- In particular, what is most emphasised as inherent to or distinctive of democracy?

- What is of most substantive or symbolic importance to democracy, and what are the most salient perceived strengths and weaknesses of democracy with relation to each of the following sub domains?

-Institutions and practices

-Rights of citizenship

-Obligations or responsibilities of citizenship.

Figure 1. Framing questions on democracy, institutions, rights, and responsibilities 
- What expectations are there about acquiring a sense of national identity or loyalty?

- How important is the sense of belonging to the nation, to communities, to traditions and institutions?

- What symbols are introduced?

- What documents (e.g. constitution), role models, historical events, ideals are considered important for citizens to know about?

- What supranational and international organisations and subnational (e.g. ethnic or religious groups) are considered important enough to have a place in the young person's awareness, identity or loyalty?

- Are either supranational or subnational groups thought of as presenting a threat to national identity or loyalty?

Figure 2. Framing questions on national identity and relations between nations

- What do young people learn about those belonging to groups that are seen as set apart or disenfranchised (e.g. by ethnicity, race, immigrant status, mother tongue, social class, religion)?

- What groups (if any) are viewed as subject to discrimination in contemporary society?

- How are instances of past oppression or discrimination dealt with in civic education?

- Are differences in participation rates or leadership roles (e.g. minorities) discussed or ignored?

- Is there tension in society between perceptions of the need for social cohesion and the need to recognise cultural, social, political or economic situations of groups?

- How is conflict between groups and between groups and society dealt with?

- Are attitudes of respect and tolerance between groups encouraged?

Figure 3. Framing questions on social cohesion and social diversity

because of their political and social similarities to Turkey and their diverse approaches to citizenship education. While comparing these countries and the civic education literature about them with Turkey, I kept in mind that non-European pluralistic societies may have other policies and practices. 


\section{Civic education in Turkey from 1923 to 1946}

The Republic of Turkey was founded on 29 October 1923, and until 1946 the Republican Peoples Party (Cumhuriyet Halk Partisi, CHP) was the only ruling organisation in Turkey. During this single-party period citizenship was defined on the basis of a single religion (the Sunni sect of Islam) and a single language (Turkish). The slogan of the period was 'one language, one culture, one ideal' and it played a significant role in constructing citizenship in Turkey. One of the most important projects of the CHP during this single-party period was to create civilised, modern citizens who were obedient to the state. This mission was reflected in the education policy of the CHP, and especially through the civic education courses they instituted.

Civics textbooks published before 1929 contained no definition of the Turkish

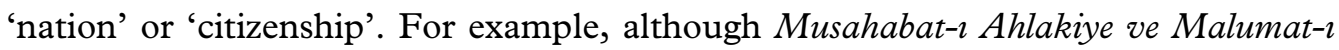
Vataniyye (Discussion of Ethics and Information about the Fatherland) used the word citizenship, it did not define it. An exception was the book MalumatVataniyye (Information about the Fatherland), which defined citizens as 'the offspring of the fatherland. Even if there are religious and language differences among them, they are fellow citizens to each other'. The book drew a distinction between vatandaş (a citizen) and milletdaş (a national), citing Armenians, Greeks and Jews living on Turkish soil as vatandas, and Turks living in Turkistan as milletdas (Üstel, 1996). This shows us that the state's understanding of citizenship was less than Turkishness.

The post-1929 textbooks do define citizenship. This period's most important civic education textbook, which can be viewed as the official citizenship cult text, was Vatandaş Için Medeni Bilgiler (Civic Information for the Citizen). Atatürk, the founder of the Republic, dictated the content of this text to his adopted daughter Afet Inan. This book is crucial for understanding how Republican elites and Atatürk himself perceived citizenship in Turkey. The 'one language, one culture, one ideal' slogan was heavily emphasised. The term nation was defined in the text as a 'political and social community formed by citizens bound by a unity of language, culture and ideal'. In addition, 'people who established the Turkish Republic are known as the Turkish nation'. These definitions appear to be inclusive until we look at Atatürk's views on what constituted the Turkish nation:

These are the historical and natural facts regarding the basis of the Turkish nation: a) political unity; b) linguistic unity; c) territorial unity; d) racial unity; e) shared history;

f) shared morality. (İnan, 1931)

This quotation reveals that race was also an element of the Turkish nation. Improbably, Atatürk also claimed that the reason for the ethnic mix in Anatolia was the result of changes brought about by living in different climatic regions. With this belief, differences among citizens were not recognised by the Republican elite.

The definition of nation in Inan's text was followed by hyperbolic praise of the Turkish nation: 'There is no state in the world which is bigger, older, or cleaner 
than the Turkish nation'. Turning to language, it continued in a similar vein, saying: 'The Turkish language is the most beautiful, richest, and easiest language in the world'. Virtues such as democracy and responsibility, valued in many countries, were also viewed as unique to the Turkish nation.

The fatherland was defined as 'the land that marks our borders and protects the Turkish nation's noble and ancient history and our struggle. Under no circumstances is this land divisible'. This definition is not expansionist or racist in terms of international relations or domestic affairs, nevertheless, it emphasises geographical and historical principles. The text indicates that geographically the fatherland of the Turks was Anatolia, whereas historically it was more than that: 'The Turkish nation lives in a great internationally recognised country demarcated by land and sea borders, one situated to the east of Europe and the west of Asia. It is called Türkeli or the Turkish fatherland'.

Non-Turkish Muslim citizens were also mentioned in İnan's text.

\begin{abstract}
In the current political and social unity of the Turkish nation, some of our citizens are being encouraged to adopt a Kurdish, Circassian, Laz or Bosnian identity. But these misnomers, which are remnants of an autocratic period from the past, have caused nothing but misery among these individuals, with the exception of a backwards and brainless few. For these members of the nation also share the same common past, history, ethics and law. (Inan, 1931)
\end{abstract}

The text, however, implicitly argued that non-Muslim citizens of the Republic were 'real citizens', asking rhetorically, 'Under the noble ethics of the Turkish nation, who could expect these citizens of christian [sic] and jewish [sic] origin to be looked down upon as "foreigner" as long as they have willingly tied themselves to the Turkish nation?’.

In terms of citizenship rights and duties the book laid more emphasis on the duties and obligations of citizens towards the state than the rights and freedoms of citizens and protection of those rights by the state. İnan maintained that Atatürk wanted every right to be complemented by a duty. Moreover, by saying 'Every Turk is born free and lives free' and 'Turks are democratic, free, and responsible citizens', Turkish ethnicity was emphasised, and only ethnic Turks were made the subject of these rights and freedoms.

Inan's book was not the only text on civic education written during Turkey's single-party period. In Yurt Bilgisi (1927), Muallim Abdülbaki defined nation as 'unity in fatherland, language, history, culture, and ideal', and then proceeded to boast of the virtues of the Turkish nation by saying 'there is no nation which is cleaner, or braver, or has higher morals than the Turkish nation'. According to other textbooks, the Turkish nation is the world's oldest and largest (Sander, 1945); it was through Turks that civilisation was spread worldwide, and Turks were the first to conceive of living in houses rather than caves (Rona, 1945); even 10,000 years ago Turks were the globe's most civilised people, and modern civilised nations learned their civilisation from the Turks (Ermat \& Ermat, 1943).

These books also argued that certain universally honoured values are in fact unique to the Turkish nation. For instance, the Turkish nation is clean and 
sublime, does not know how to tell a lie, fears no enemies, has high morals and is brave and hospitable (Sander, 1945). The texts emphasised the importance of being born a Turk, living as a Turk and dying as a Turk. They quoted Atatürk periodically throughout their pages, with such sayings as, 'How happy is the one who says, I am a Turk', and maintained that proving the expression 'strong like a Turk' was the most important duty of Turkish youth. While a certain degree of national pride is commendable, by exaggerating the qualities of being Turkish, prejudice against the 'other' was created in the minds of the young people studying these texts.

The definitions of Turkish nationalism in texts published during the single-party period were not expansionist in terms of national territory; however, some authors explicitly or implicitly referred to 'Outside Turks'. Abdülbaki (1929) maintained that 'the Turkish nation is a large family, one sharing identical interests'. Some books also gave a broad definition of the Turkish fatherland. For example, Kazım Sevinç (1931) asserted that '[ $t$ ] he boundless lands where Turks dwell is what we know as the Turkish fatherland', referring to 'Outside Turks' living in Asia. For Mithat Sander (1945), Turkey meant 'great Turkish homeland'. Throughout their course children were urged to learn by heart the motto, 'I love the fatherland more than myself, even more than I love my mother'.

One text defined citizens as 'those Turks who live in Turkey' (Ermat, 1945), which implies that in order to be a citizen one had to be an ethnic Turk. It was argued that all citizens of the country have the same rights and duties. The rights of citizens were defined with references to the 1924 constitution, which listed the basic rights and freedoms of citizens, but lacked specific provisions to protect them.

Civics texts published during this period emphasised citizens' duties more than citizenship rights. The purpose of the civics course was defined in one of the books as 'teaching the duties of citizenship' (Emin, 1930). To deserve rights 'citizens should firstly fulfil their duties, because duties and rights are inseparable' (Abdülbaki, 1929). Chief among these duties was performing military service (then, as now, required only of males), a duty justified by the large number of Turkey's enemies (Sevinç, 1931). Living cleanly, being polite, and staying physically active were other citizenship duties, related to creating such citizens for the Republic. One text argued that '[w]e should not cause our enemies to claim that Turks are not civilised' (Abdülbaki, 1929). The texts hold interesting indications about the pressure to create modern citizens. For instance, one book showed pictures of a child involved in a sports activity in unrelated sections, such as in a part stressing the importance of paying taxes (Sevinç, 1931). The textbooks generally concluded with the motto of 'Dear children, never forget your duty to the fatherland'.

The textbooks discussed the major enemies of the Turkish Republic, citing them as France, Britain and Greece. One text listed the enemies of the nation as 'greeks, french, and armenians [sic]', using small letters in an apparent effort at denigration (Yurt Bilgisi, 1937). Abdülbaki's 1929 text titles one section Fena Adamlar 
(Bad People), which brands non-Muslim citizens of the Republic as 'bad people'; faizciler (usurers), madrabazlar (swindlers) and muhtekirler (profiteers). The book blasted these 'bad people', arguing they were 'not from our nation, as there is no Turk that is so stone-hearted'.

Throughout these courses, the textbooks also inculcated the 'Sèvres Syndrome', which refers to the conviction that Turkey is surrounded by enemies intent on dividing it, à la Treaty of Sèvres, ${ }^{4}$ which was imposed on the Ottoman government by the victorious Western powers at the end of the First World War. According to one survey, $72 \%$ of Turkish citizens believe that there are some countries that would like to divide Turkey (Guida, 2008). There are also fears that Christian, Kurdish or Armenian minorities living in Turkey are colluding with foreign powers to divide and destroy the country. The Sèvres Syndrome inevitably leads to irrational overreaction and behaviour by the masses and by politicians. Failing to understand this paranoia prevents full comprehension of contemporary Turkish politics.

\section{Civic education in Turkey from 1946 to 1960}

This period starts with the establishment of the Democrat Party (Demokrat Parti, DP) in 1946 and ends with the 1960 military intervention. During this period certain laws about citizenship were liberalised. This liberalisation can also be seen in civics textbooks, which emphasised democracy and citizenship rights more than they did in the previous period. However, the DP, which held power from 1950 to 1960, made no revolutionary changes in educational policy, keeping the CHP's policies and education programmes intact.

The influence of multi-party politics can particularly be seen in texts published after 1950, the year the DP came to power. The books began explaining the concept of democracy and the role of political parties in a modern democracy. Moreover, unlike the single-party period, one author maintained the importance of establishing and belonging to foundations as one of the basic characteristics of democracy. However, it was emphasised in bold letters that such foundations were only allowed if they did not conflict with the interests of the community (Aksan, 1956).

The textbooks also discussed citizenship rights and duties. Some gave the full text of the Universal Declaration of Human Rights and, unlike the single-party period, pointed out that citizenship rights should be under the protection of the state. Nevertheless, the textbooks also talked about martial law, a tool for limiting citizens' rights for a certain time in extraordinary situations. By doing this these books normalised the limitation of citizens' basic rights under certain circumstances.

Between 1946 and 1960 the textbooks' definitions of nation were no different from those in the single-party period. Nation was defined as a community living in the same fatherland, speaking the same language and sharing the same historical connections, emotions, thoughts and ideals (Aksan, 1952). The standard exaggerations of the virtues of the Turkish nation were also observed during this period, although less pronounced. Some texts, however, define race and religion as the 
basic characteristics of citizenship in Turkey and differentiated the meaning of citizen from dindas (coreligionist), azmllk (minority) and yabancı tebaa (foreign subject) (Aksan, 1957).

As in the single-party period, the major purpose of the textbooks during the DP's reign was to create modern and civilised citizens. They discussed newspapers, books, radio programmes, conferences, cinema, theatre and music that could serve to educate and enlighten the citizenry. Students were urged to listen to classical music, told by the texts that although Beethoven was a foreigner, when Turks listened to his symphonies they could appreciate them as much as his fellow Germans did (Arkın, 1953).

The authors continued branding the Treaty of Sèvres as a blueprint for dividing Turkey. The Treaty of Lausanne, ${ }^{5}$ in contrast, was lauded as an instrument of Turkey's salvation. One book unfavourably contrasted a map of Turkey under the Treaty of Sèvres with the same under Lausanne. The maps were placed in an unrelated section of the book (Arkın \& Su, 1956), and thus, authors continued indoctrinating students with the Sèvres Syndrome.

\section{Civic education in Turkey from 1960 to 1980}

This period starts with the 1960 military intervention and ends with the 1980 military intervention. A constitution was enacted in 1961 and a more liberal understanding of citizenship emerged and was reflected in the civics textbooks. Although all texts published during this period emphasised the importance of democracy and multi-party politics, they called the military intervention of 27 May 1960 the '27 May Revolution', implying support for it. This event was hailed as key for the Turkish nation, one as important as the declaration of the Republic.

The citizenship studies syllabus prepared by the education ministry to suit the 1961 constitution gave much attention to such topics as the duties of the state towards citizens and respect for citizens and their rights. The textbooks published during this period gave the same definition of nation as in previous periods, namely, unity in history, culture, the fatherland, language and ideals. The basis of Turkish nationalism was described as 'Everybody and everything is for Turkey'. 'Every Turk', said the texts, should carry the feeling of 'I am a Turk, and I am proud to be a Turk'. The single-party period's policies of promoting self-confidence among the citizenry and exaggerating the virtues of the Turkish nation were continued.

The textbooks of this era defined Turkish citizens as 'anyone attached to the Turkish nation by citizenship ties'. One text defined citizens as:

Those who are tied to the Turkish state according to the conditions of the laws .... Everybody who is tied to the Turkish state through citizenship ties are all Turks. In this respect those citizens living in Turkey whom we call Armenians, Greeks and Jews are Turks. There is no difference between them and those born of Turkish parents. (Pazarl1, 1964)

However, other citizens' rights, such as being able to believe in and freely practise one's religion, should be respected, according to the text: 
Our constitution gives our citizens freedom of conscience. Based upon this it is a violation of citizenship rights to make fun of a Christian citizen who goes to church for fulfilling his religious duties. (Pazarl1, 1964)

The syllabus published by the Teaching and Education Committee in 1969 was the one that most encouraged active citizenship thus far, motivated by the European Council's 1969 'General and Technical Education Report'. This report proposed methods of teaching citizenship information in schools, and emphasised the importance of participatory education and critical thinking. Unfortunately, this period only lasted until 1971, when the military again intervened in the government. Civics texts published after the 1971 memorandum resumed the theme of emphasising duties more than rights. One of the texts defined individual rights as 'something that citizens want in return for having fulfilled their citizenship duties' (Erdem \& Konuk, 1972).

\section{Civic education in Turkey from 1980 to 2010}

This period starts with the 1980 military intervention, after which course books were reorganised and the curriculum began to favour the military's perspective in terms of social and political events. Author Kemal Inal wrote that post-1980 education, both in general and regarding textbooks in particular, had become a tool for ideological indoctrination (İnal, 1996).

Texts published after 1980 define the nation as a union of language, religion, race, history and culture, where the orthodox understanding of religion especially has begun to be counted among the basic characteristics of the nation. By doing this, hatred against non-Muslim citizens and citizens belonging to different sects of Islam is supported.

The texts define citizenship rights by referencing the 1982 constitution and then present the constitutional limitations of these rights and freedoms; the state sees limiting the rights of its citizens under certain circumstances as one of its duties. For such a course to teach that students' rights can be limited by the constitution while simultaneously blocking criticism of that constitution is truly irrational. The textbooks present the existing situation as ideal and do not discuss problems that citizens face while trying to exercise their rights. The texts also fail to address the importance of citizenship participation in the policy process and reduce democracy merely to voting.

Critical thinking is not found in Turkish civics texts. They encourage rote memorisation of sayings such as 'Peace at home, peace in the world', 'Idleness is the father of all vice' and 'Turkish nation! You should be proud, hardworking and confident'. Their aim is to instil the state's ideology into young people and teach them to bow to authority.

Not unexpectedly, these textbooks-like those of previous periods-create a phobia of 'the enemy' in the minds of young people. Unlike in previous periods, however, the texts warn not only of external enemies but also of internal ones. Internal enemies, say the books, seek to divide Turkey along lines of race, class 
and religious sect, and use various methods towards this end, such as anarchy and terror. External threats are listed as smuggling, international terrorism, certain countries' (Greece, Armenia, Syria and Russia) historical and ideological designs and, finally, espionage (Bilgen, 2001). As the saying goes, 'Turks have no friends besides fellow Turks' (Ceylan, 1996). The state uses civic education as a tool to develop 'self-sacrificing' 'good citizens', who should always be alert for 'enemies' and ready to protect the unity of the nation. This has burdened young citizens with a great responsibility and fosters xenophobia.

Since 1998, Vatandaşlık ve Insan Haklar (Citizenship and Human Rights) has been implemented in Grades Seven and Eight as a weekly one-hour required course. The importance of human rights and international humanitarian organisations is now emphasised, not because of changing moral or ethical principles, however, but because doing so is a mark of a civilised country. Promoting human rights is only a vehicle to promote Turkey's reputation and respectability on the international stage (Gök, 2003). The Justice and Development Party (Adalet ve Kalkinma Partisi, AKP), which has faced objections from some segments of society that it harbours an Islamist agenda that could undermine Turkey's secular foundation, came to power in 2002. The AKP government's 2006 decision to censor the Grade Seven Vatandaşlık ve Insan Haklar text is evidence of the above mentioned argument. The book contained a reproduction of the renowned 'Liberty Leading the People', by French painter Eugene Delacroix, and Liberty's breasts are bare. ${ }^{6}$ The censoring opened up a new debate on civic education in Turkey. One columnist said, 'This work is a symbol of the French Revolution ... and as such [is a symbol of] not only France but global democracy'. ${ }^{7} \mathrm{He}$ suggested, tongue in cheek, that if students are to be protected from bared bosoms, they should be 'banned from museums'. The leader of the teachers' union also stated that the government was in the process of imposing its worldview in schoolbooks. ${ }^{8}$

Since the 2008-2009 academic year Turkey's Ministry of National Education has incorporated civic education into social studies textbooks for Grades Six and Seven. The courses include history, geography, general culture and civic information. There are several similarities between the civics textbooks published before 2008 and the social studies textbooks published after 2008. The current social studies texts emphasise duties more than rights. The textbooks connect ancient civilisations and the Turkish nation; one emphasises the similarity between the Sumerian and Turkish languages and implies that the Sumerians were Turkish (Genç et al., 2009). The texts emphasise similarities between Muslim countries and Turkey and underscore cultural and language similarities between Turkey and the Turkic Republics. One of the textbooks states that '[o]ur state has a very good relationship with all states; however, we have much closer ties with our soydaşlar (people who share the same race) living in different countries' (Polat et al., 2009).

There have been some improvements in the social studies textbooks, the most important of which concerns teaching techniques. The course supports class participation rather than rote learning. Sèvres Syndrome-thinking has also been removed. There is no talk about 'enemies of Turkey', thus decreasing the 
likelihood of xenophobia. When discussing religious freedom, one text gives the example of Antakya, a city in Turkey where three different religions peacefully co-exist. However, apart from this brief mention, the textbooks still do not discuss the ethnic and religious minorities living in Turkey and their identity claims. One text mentions Nevruz, the traditional celebration of the Iranian new year. The text reads as if Nevruz is celebrated by ethnic Turks only; however, Kurdish citizens traditionally celebrated Nevruz but could not do so openly until 2005. Although the holiday is now recognised in Turkey, there is no mention in the texts of Kurds living in Turkey.

Effective citizenship education requires teaching tools, including textbooks that promote human rights and related values such as tolerance and peace. Fortunately, there have been a few promising efforts to that end in Turkey. Some non-governmental organisations have started to play active roles in developing appropriate instructional materials on civic education. For instance, a text entitled Yurttas olmak için (To Be a Citizen) was prepared by a team of law and education scholars under the sponsorship of Umut Vakfi (the Hope Foundation). That book is the first to employ interactive methodologies in teaching citizenship and human rights courses. Demokratik Yurttaşlı Eğitimi (Democratic Citizenship Education) was launched by the Education Committee of the Council of Europe in 1997. This project has been accelerated through the proclamation of 2005 as 'European Citizenship Year through Education' and in Turkey was implemented by the National Ministry for Education and continued through the contribution of civil society organisations, universities and various other groups. It was expected that there would be significant successes in the field of citizenship education as a result of this project, although as of 2010 there have been no tangible results. The current civics curriculum in Turkey merely creates dutiful citizens who obey state dictates (whether appropriate or not) and at best feel ambivalent towards tolerance. Unfortunately, for all the above reasons, current civics education in Turkey is not up to the task of cultivating the democratic, tolerant, active and participatory citizens needed in the 21 st century.

\section{Analysis and comparisons}

In this section I summarise my findings and compare the Turkish case with phase one of the IEA's study results from France, England, Greece and Cyprus. The findings provide information for reconsidering citizenship education in other multicultural societies and for promoting an active national citizenry in Turkey.

Turkish civic education textbooks appear to base nationalism on citizenship, with vaguely political definitions, but in reality they promote an ethno-cultural nationalism based on race. The texts argue that that the word 'Turk' has no racial meaning but embraces everyone who lives in Turkey, yet ethno-cultural definitions of Turk are emphasised more than the political ones are; equating 'Turkishness' with being Muslim is one example (Bora, 2003). Moreover, the texts are replete with signs of pan-Turkism, referring continually to 'Turkish-originated' countries 
and communities. Sexual, cultural and class identities are presented as unimportant; only national identity is significant. The texts skirt discussion of ethnic groups and religious beliefs in Turkey and avoid entirely such matters as religious uprisings and identity claims.

The books also exaggerate the virtues of the Turkish nation. Being a Turk is equated with being good and perfect and certain virtues are argued as being specific to Turks. The numerous quotations from Atatürk in the course books are meant to cultivate self-confidence and national pride among young citizens, but they also cause hatred towards minorities. As Tanil Bora stated, one of the basic characteristics of a nationalist ideology is an effort to differentiate that nation from others; in Turkey, however, this characteristic is carried to extremes.

The textbooks raise the spectre of threats from other countries at every turn. This 'threat cult' encourages hostility towards the outside world and lacks a rational basis, implying that certain nationalities are the enemies of Turks and Turkey by birth. Citizens belonging to Turkey's majority-i.e., Sunni ethnic Turks - do not want to extend rights to ethnic and religious minorities, fearing a return to the conditions of the Treaty of Sèvres, whose dangers were driven into young people throughout the civics courses. The texts also show militaristic pictures of tanks, anti-aircraft weapons, soldiers, guns and so on, which are pedagogically wrong for students to be viewing.

The texts' definitions and treatment of such concepts as democracy and civic participation are poor. Multi-party politics is defined as the most significant feature of democracy; none of the books discusses civil society or the active participation of citizens (apart from voting), though together these are the most crucial features of democracy. These textbooks paint a rosy picture of Turkey, especially concerning the practice of citizens' rights and the freedoms. They reference the 1924 and 1982 constitutions, both of which have been judged undemocratic.

Incorporating citizenship rights themes into school curricula is challenging for a dominant political culture. This is valid in the Turkish case, where the single-party policies of prioritising stability, unity, security and order still define politics. In France, civic education has also traditionally been high on the political agenda and intended to help integrate a diverse population into a single national culture defined as Republican (Osler \& Starkey, 2001). As in Turkey, citizenship in France is intrinsic to the whole notion of state schooling. The basis of state education in France is initiation into a common culture through the curriculum. It does not recognise differences but starts from the premise that, within the Republic, all citizens are equal. The French concept of citizenship, like the Turkish one, has always intentionally neglected social, socio-economic and cultural pluralist dimensions for fear that social fragmentation may lead to the destruction of the Republican ideology (Lefebre, 2003). As in the Turkish case, French textbooks contain a section on threats to the Republic, highlighting the armed Corsican independence movements. In France the only suggestion of cultural diversity concerns regional traditions of food and folklore and objects held in museums and art galleries. Mosques, however, are omitted. In the textbooks there is little to suggest that 
minorities may be subject to discrimination, except at the hands of far-right political parties. The reluctance to recognise community identities, however, has engendered conflict and difficulties for schools, as evidenced by various headscarf issues since 1989.

In England, citizenship education became compulsory for 11- to 16-year-olds in local authority-funded schools (Kerr, 1999), following the publication of the Crick Report (Crick, 1998). This report's recommendations appear to mark a considerable step forward, given the neglect of citizenship education in England in the past. Crick advocated three strands of citizenship education: social and moral responsibility, community involvement, and political literacy. There are, however, a number of contradictions and omissions in the report that undermine its good intentions. The report fails to recommend a central role for the anti-discriminatory practice that must be at the heart of citizenship education if important barriers to the development of mutual respect and recognition such as racism, sexism and homophobia are to be tackled. The report also fails to examine the institutional context through which citizenship education is to be delivered (Faulks, 2006). David Gillborn (2006) pointed out that in Britain the dominant tradition has been citizenship education that reinforces the status quo by binding students to a superficial and sanitised version of pluralism that is long on duties and responsibilities, but short on popular struggles against race inequality. Although the British programme of study roundly condemns racism and recognises different ethnic groups, it does not give significant weight to the perspectives of minorities. According to Gillborn, it is in this context that the promotion of citizenship education in England can be seen as a public policy placebo, that is, a pretend treatment for institutional racism that gives the impression of action, but is, in fact, without substance or effect. Nevertheless, England now has a fourth dimension to its citizenship policy: 'identity and diversity: living together in the UK', which helps students gain a broad understanding of the country they are growing up in. Students learn to appreciate and understand the diversity of their society through opportunities offered as part of the curriculum.

In Greece, civic education was introduced into the secondary school curriculum in 1931 (Makrinioti \& Solomon, 1999). As in the Turkish case, strengthening national morale and identity was overemphasised. Military-like behaviour and attire were encouraged, and through the teachings, the government tried to create passive and duty-oriented citizens. Greece's curricula and textbooks today are the product of the country's 1981 educational reforms. The texts are characterised by content aimed at reducing social and gender inequalities in schools as well as at promoting social equity and critical thinking. However, according to the IEA results, sensitivity regarding these issues is not concretely represented. Discussion of ethnic, linguistic, religious or other minorities is absent. Emphasis is placed on a homogeneous image of the Greek nation. Stereotypes continue to survive and students are not offered tools to understand critically the mechanisms that underlie social cohesion. The texts exaggerate the qualities of the Greek nation, which is described as 'superior to any civilization that ever existed'. They emphasise a 
homogeneous representation of Greece through time (the nation is described in the texts as having commonality, unity, uniformity of biology (descent), and culture), neglecting to include minorities, and they negatively represent 'national others'. As in Turkey, the texts talk about national enemies and create a threat cult in the minds of youth; Greece apparently lives under threat of attack from malevolent neighbours. Regarding citizenship, the books define citizens as people belonging to the polity and having certain rights and obligations, 'irrespective of their religion or language, or even their ethnicity'. '[O]r even' can be interpreted as showing a certain reluctance on the part of the authors to define citizenship irrespective of ethnicity, especially after having stated a few pages earlier how important ethnicity, as well as religion and language, is for the definition of nation, and after referring to Greece as one of the most ethnically homogeneous countries in Europe.

According to the IEA study, the aim of civic education in Cyprus, as defined in the curriculum of its Ministry of National Education, is to help students to develop into free, responsible and democratic citizens, who will, in turn, perform their duties according to their conscience (Papanastasiou \& Koutselini-Ioannidou, 1999). Their textbooks begin with a map of Cyprus and the military boot of the Turkish invader stepping on the northern part. The text accompanying the picture states: 'The territorial integrity and sovereignty of the Republic of Cyprus were flagrantly violated by the Turkish invasion of 1974'. The texts contain negative statements about Greece's neighbours (e.g., Turkey and Bulgaria), and Greece is presented as superior to them. To strengthen Greek national identity for Greek Cypriots, the Cypriot flag is represented as the flag of the country and the Greek flag is represented as the flag of the nation. There is no content in the textbooks about minority groups in Cyprus, which reflects a lack of tolerance.

As seen from the above examples, citizenship education is a difficult task. Not only Turkey but other countries have difficulties incorporating inclusive citizenship rights themes into school curricula. The irony is that those are the countries that need to improve their citizenship education in order to foster tolerance, trust, mutual understanding and solidarity among their citizens.

\section{Conclusion}

The civic education discourses of democracy, national identity, and social diversity adopted in civics textbooks and, later on, in social studies textbooks in Turkey are regrettably out of step with contemporary political and social reality. Citizenship education must be reconsidered in terms of its aims, knowledge and content, and its process of developing meaning. Turkey's national curricula should be responsive to minority as well as majority perspectives, otherwise it will remain exclusive. That people's identities are multiple and dynamic, traversing gender, religion, class, region and ethnicity must be recognised. This means that integration in Turkey should not attempt to reduce citizenship to a single identity (i.e., being Turkish). Against the background of Turkey's considerable diversity, it is hard to 
imagine such integration without citizenship education that promotes relationships based upon trust, mutual respect and dialogue.

\section{Notes}

1. Since the 1997-1998 education year, compulsory basic education in Turkey has comprised eight years. Previously, it was five years.

2. Unfortunately, there is no exact information on the percentages of students who were enrolled in primary and junior high schools in the periods 1923-1946, 1946-1960 and 1960-1980. This is a limitation of the study.

3. France did not participate in the IEA phase one research, but Osler and Starkey, in their article 'Citizenship Education and National Identities in France and England: inclusive or exclusive?', applied framing questions related to 'National Identity and Relations between Nations' and 'Social Cohesion and Social Diversity' to civic education textbooks in France.

4. The Treaty of Sèvres (10 August 1920), which dissolved the Ottoman Empire and virtually abolished Turkish sovereignty, was the peace treaty between the Ottoman Empire and its allies at the end of the First World War. The treaty was annulled during the Turkish War of Independence led by Atatürk.

5. The Treaty of Lausanne was signed in Lausanne on 24 July 1923 . This treaty replaced the Treaty of Sèvres.

6. Turkish Daily News, 21 October 2006.

7. Milliyet, 21 October 2006.

8. Radikal, 22 October 2006.

\section{Notes on contributor}

Başak Ince studied for her PhD in politics at the School of Oriental and African Studies and her Master's in comparative politics at the London School of Economics and Political Science. Currently she is an instructor at Bilkent University in the department of Political Science, teaching courses which include State, Society and Citizenship in Turkey; Politics of Conflict Resolution; and Turkish Political Development.

\section{References}

Abdülbaki, M. (1927) Yurt Bilgisi (İstanbul, Maarif ve şark Kitaphaneleri).

Abdülbaki, M. (1929) Yurt Bilgisi (İstanbul, Türk Neşriyat Yurdu).

Aksan, H. (1952) Orta Okul Yurttaşlık Bilgisi Sinıf II (İstanbul, Güven Basımevi).

Aksan, H. (1956) Yurttaşlık Bilgisi Sinıf III (İstanbul, D.K).

Aksan, H. (1957) Yurttaşlık Bilgisi (İstanbul, Maarif Basımevi).

Arkın, M. (1953) Yurttaşlık Bilgisi Sinn: 5 (İstanbul, Bir Yayınevi).

Bilgen, H. N. (2001) 8. Simf için Vatandaşlık ve Insan Haklan Eğtimi (Ankara, MEB).

Bora, T. (2003) Ders Kitaplarında Milliyetçilik, in: B. Çötüksöken, A. Erzan \& O. Silier (Eds)

Ders Kitaplarnda Insan Haklar: Tarama Sonuçlar (İstanbul, Tarih Vakfı Yayınları), 69-70.

Brighouse, H. (2000) School choice and social justice (Oxford, Oxford University Press).

Brighouse, H. (2006) On education (London, Routledge).

Ceylan, E. (1996) Ilkögretim Vatandaşlık Bilgileri, 8 (Ankara, SEK Yayınları).

Crick, B. (1998) Education for citizenship and the teaching of democracy in schools: final report of the Advisory Group on Citizenship (London, QCA). 
Çayır, K. (2007) Tensions and dilemmas in human rights education, in: Z. F. Kabasakal Arat (Ed.) Human rights in Turkey (Philadelphia, University of Pennsylvania Press), 233-245.

Çayır, K. \& Gürkaynak, İ. (2008) The state of citizenship education in Turkey: past and present, fournal of Social Science Education, 6(2), 50-58.

Emin, M. (1930) Yurt Bilgisi (Kanaat Kütüphanesi).

Erdem, S. \& Konuk, İ. (1972) Yurttaşlı Bilgisi: Ortaokul III (İstanbul, Atlas Yayınevi).

Ermat, B. \& Ermat, K. (1943) Yurt Bilgisi Dersleri: IV. Sinnf (İstanbul, Milli Eğitim Basımevi).

Faulks, K. (2006) Rethinking citizenship education in England: some lessons from contemporary social and political theory, Education, Citizenship and Social fustice, 1(2), 123-140.

Genç, E., Polat, M., Başol, S., Kaya, N., Azer, H., Gökçe, S., Koyuncu, M., Gök, A., Yıldız, A., Yılmaz, D. \& Özcan, A. (2008-2010) İlkögretim Sosyal Bilgiler 6 Ders Kitabı (Ankara, MEB).

Gillborn, D. (2006) Citizenship education as placebo: 'standarts', institutional racism and education policy, Education, Citizenship and Social fustice, 1(1), 83-104.

Gök, F. (2003) Vatandaşlık ve İnsanhakları Eğitimi Ders Kitapları, in: B. Çötüksöken, A. Erzan \& O. Silier (Eds) Ders Kitaplarnda Insan Haklarn: Tarama Sonuçlarn (İstanbul, Tarih Vakfı Yayınları), 158-172.

Guida, M. (2008) The Sèvres Syndrome and 'Komplo' theories in the Islamist and secular Press, Turkish Studies, 9(1), 37-52.

Gutmann, A. (2000) Democratic education (Princeton, Princeton University Press).

İnal, K. (1996) Egitimde Ideolojik Boyut (Ankara, Doruk Yayınları).

İnan, A. (1931) Vatandaş Için Medeni Bilgiler (İstanbul, Devlet Matbaası).

İnan, A. (1988) Medeni Bilgiler ve Mustafa Kemal Atatürk'ün El Yazllarn (Ankara, Türk Tarih Kurumu Basımevi).

Kerr, D. (1999) Re-examining citizenship education in England, in: J. Torney-Punta, J. Schville \& J-A. Amedo (Eds) Civic education across countries: twenty-four national case studies from the IEA Civic Education Project (Amsterdam, IEA), 203-227.

Kıncal, R. Y. (2002) Vatandaşlık Bilgisi (Ankara, Mikro Basım).

Lefebre, L. E. (2003) Republicanism and universalism: factors of inclusion or exclusion in the French concept of citizenship, Citizenship Studies, 7(1), 15-36.

Makrinioti, D. \& Solomon, J. (1999) The discourse of citizenship education in Greece: national identity and social diversity, in: J. Torney-Purta, J. Schville \& J-A. Amedo (Eds) Civic education across countries: twenty-four national case studies from the IEA Civic Education Project (Amsterdam, IEA), 285-311.

Osler, A. \& Starkey, H. (2001) Citizenship education and national identities in France and England: inclusive or exclusive? Oxford Review of Education, 27(2), 287-305.

Papanastasiou, C. \& Koutselini-Ioannidou, M. (1999) National identity in the civic education of Cyprus, in: J. Torney-Purta, J. Schville \& J-A. Amedo (Eds) Civic education across countries: twenty-four national case studies from the IEA Civic Education Project (Amsterdam, IEA), $162-177$.

Pazarlı, O. (1964) Yurttaşlık Bilgisi Sinf II (İstanbul, Yükselen Matbaası).

Polat, M., Kaya, N., Koyuncu, M. \& Özcan, A. (2009) İkögretim Sosyal Bilgiler 7 Ders Kitabı (Ankara, MEB).

Rona, T. (1945) Yurt Bilgisi Dersleri (Ankara, Çankaya Matbaası).

Sander, M. S. (1945) Yurt Bilgisi Özü (İstanbul, İnkılâp Kitabevi).

Sevinç, K. (1931) Türk Yavrularna Yurt Bilgisi: Sinff 5 (İstanbul, Ekspres Matbaası).

Torney-Purta, J., Schville, J. \& Amedo, J-A. (1999) Civic education across countries: twenty-four national case studies from the IEA Civic Education Project (Amsterdam, IEA).

Üstel, F. (1996, 25 April) Yurttaşlık Bilgisi Kitapları ve Yurttaş Profili, Yeni Yüzynl.

Üstel, F. (2005) Makbul Vatandaş'in Peşinde (Ankara, İletişim Yayınları).

Yurt Bilgisi: Ilkmektep Kitaplarn IV. Sinf, (1937) (İstanbul, Devlet Basımevi). 